\title{
The invisible victim in criminal policy
}

\author{
HEINI KAINULAINEN ${ }^{\star}$, PÄIVI HONKATUKIA** $\&$ JOHANNA NIEMI ${ }^{* * *}$
}

\section{Introduction}

Crime victims have long been invisible in Finnish criminal policy. Since the 1970s, criminal policy has focused on reducing repression and the number of prison inmates. There has been progress towards these goals. Such progress, in particular the reduction in the number of prisoners, has drawn international attention and even admiration for the Finish criminal policy's humanity and rationality. Rationality of the criminal law has found expression in the new classical school of criminal law, according to which the sanctions should be in proportion to the severity of the crime and criminal sanctions should only be used when necessary to prevent crime, in opposition to symbolic criminalisation. Criminal justice should be used for the management of social problems as sparingly as possible. ${ }^{1}$ The realisation of the ideals of humanity and rationality has been studied less from the perspective of the victim. There has been a fear that highlighting the victim's plight would lead to an increase in the severity of penalties. This article argues it is nonetheless important to also evaluate criminal policy from the perspective of the victim.

In this article, we first explore the international criminological discussion, represented by David Garland and Jock Young, and the punitive turns in criminal policy during the 1980s and 1990s. Then in part III, we turn to the Finnish exceptionalism, in which the experts have had a considerable role in forming and defending the lenient criminal policy. Parts IV and V focus on the position of the victim in the international as well as in the Finnish criminological discussion. In part VI we claim that the victim issue has been hijacked as a tool for those who seek a more punitive criminal policy without

* Kainulainen, Heini, Senior researcher, Finnish Non-discrimination Ombudsman office, LL.D., Docent, Faculty of Law at the University of Turku. Email: heini.kainulainen@utu.fi.

** Honkatukia, Päivi, Professor, Faculty of Social Sciences at the University of Tampere. Email: paivihonkatukia@tuni.fi.

*** Niemi, Johanna, Professor, Faculty of Law at the University of Turku.Email: johanna.niemi@utu.fi.

This is an Open-access article distributed under the terms of the Creative Commons Attribution 3.0 Unported License (http://creativecommons.org/licenses/ by/3.0/), permitting all use, distribution, and reproduction in any medium, provided the original work is properly cited. 
really asking victims of crime what they actually want. In parts VII we present briefly main results of studies that have asked the victims about their experiences and wishes. In conclusion, the article claims that we should be ready to an open and sensible discussion of criminal policy in which the victim's perspective is taken seriously.

\section{Changes in the climate of criminal policy}

Analysing the criminal policies in the United Kingdom and the United States, David Garland argues that a criminal policy based on a welfare state ideology has reached a crisis. Historically, the situation differs from the 1970s, when there was a desire to support perpetrators who came from difficult backgrounds. At the time, there was a strong belief that levelling social inequality would decrease crime. Despite good intentions, statistically registered crime increased sharply. This had two consequences. First, the state had to admit it failed in its attempt to reduce crime through welfare policy. Second, the increase in crime damaged the public faith in experts on criminology and criminal policy. ${ }^{2}$

Jock Young discusses inclusion and exclusion, or inclusive and exclusive policies. Young states that it is typical in our era to create a competitive society based on opposition, in which winners are successful, but losers have to suffer. Losers are separated, isolated and excluded from the rest of the society and from the winners in particular. As tolerance in society decreases, resentment and control are directed at entire groups of people who become scapegoats in the criminal justice system and other control mechanisms of the state. Few people are interested in defending the losers or in the negative consequences of control on them. ${ }^{3}$

Garland expresses similar views when discussing changes in criminal policy. This illustrates a tension between the perpetrator and the victim. According to Garland, disappointment in welfare state-based criminal policy was gradually channelled into public debate through emotionally appealing populism, in which everyone saw themselves as potential crime victims. People have become risk conscious and developed practices to protect themselves against crime. According to Garland, the public grew

1 Lappi-Seppälä, Sentencing and Punishment in Finland: The Decline of Repressive Ideal in Finland in Sentencing and Sanctions in Western Countries, eds. Torny and Frase (Oxford University Press 2001) pp. 92-150; Lappi-Seppälä and Nuotio, Crime and Punishment in Nordic Law in European Context, eds. Letto-Vanamo, Tamm, and Gram Mortensen (Springer 2019) pp. 179-200; Anttila, and Törnudd, The Dynamics of the Finnish criminal Code Reform in Criminal Law Theory in Transition. Finnish and Comparative Perspectives, eds. Lahti and Nutio (Finnish Lawyers' Publications 1992) pp. 11-26.

2 Garland, The Culture of Control. Crime and Social Order in Contemporary Society (University of Chicago Press \& Oxford University Press 2001).

$3 \quad$ Young, Exclusive Society (Sage 1999). 
tired of being afraid and demanded harsher punishments. A change in the attitude toward perpetrators diminished sympathy for them. Those labelled as criminals were seen as rational and calculating individuals who had chosen a career of crime. This climate encouraged decision-makers to deploy harsh measures to fight crime. The populist rhetoric requires that criminals must be identified and isolated in prisons preferably for a long time. This policy has had substantial consequences: The number of prison inmates, particulary in the United States, has risen sharply. ${ }^{4}$

\section{The cooling of the climate in the Nordic countries}

Nordic countries have also experienced a similar kind of cooling climate regarding criminal policy as described above. A significant work, Warning For Punishment, published in the mid-1990s, highlighted signs of change similar to those discussed by Garland. ${ }^{5}$ Of Finnish researchers, Tapio Lappi-Seppälä in particular has been following - with concern - the new criminal policy debate. For example, some right-wing politicians have been vocal in airing their views in the media on the need to tighten control. Lappi-Seppälä notes that in the populist rhetoric links to structural social problems have a minor role when a solution is sought from the criminal justice system. The ultima ratio principle has been forgotten. Criminal policy that emphasises individual risks have become increasingly common for general policy making that favours easy and quick solutions instead of trying to identify the structural foundations of the problem, such as poverty or inequality. This results in simple solutions to complex problems and can feed into a public opinion yearning for punishment and increased repression. This punitive turn has also had consequences in Finland: the number of prison inmates began to rise after the turn of the millennium. ${ }^{6}$ Lappi-Seppälä has rightly asked why so much money has been spent on increasing the number of inmates when the adoption of cheaper alternatives to prison has simultaneously been rejected for lack of funds. ${ }^{7}$ However, in a European comparison, Finland has much lower incarceration rates. Lappi-Seppälä argues that despite such recent populist turns, a clear social policy orientation still underpins Finnish penal policy. It reflects the values of the Nordic welfare state ideal and emphasises that measures against social marginalisation and inequality also work as measures against crime. ${ }^{8}$

\footnotetext{
$4 \quad$ Garland 2001.

5 Snare (ed.), Beware of Punishment. On the Utility and Futility of Criminal Law (Pax 1995).

$6 \quad$ Lappi-Seppälä 2001 pp. 92-150; Lappi-Seppälä, Penal Policies in the Nordic Countries 19602010, 13 Journal of Scandinavian Studies in Criminology and Crime Prevention. (2012) pp. 85-111; Lappi-Seppälä, Nordic Sentencing, 45 Crime and Justice. A Review of Research (2016) pp. 17-82.

7 Lappi-Seppälä, Rangaistuskäytännön hinta in Rikosoikeudellisia kirjoituksia VIII Raimo Lahdelle. Suomalaisen Lakimiesyhdistyksen julkaisuja A-sarja 268 (2006) pp. 181-214.

$8 \quad$ Lappi-Seppälä, Penal Policy in Scandinavia, 36 Crime and Justice (2007) pp. 217-295.
} 
Many Finnish researchers have also problematised the change in societal control from welfare policy to risk policy and culture of intervention. Exclusive policies, where risky individuals should be identified as early as possible, are becoming increasingly popular. According to these scholars, tolerance in society has decreased and young people, in particular, are being singled out and targeted by various disciplinary campaigns. For example, citizens have been encouraged to take responsibility for fighting crime and for their own personal security. Various security projects and partnerships between civil society, the private sector, and governmental power in fighting crime have also grown popular. ${ }^{9}$

\section{Have crime victims been hijacked as tools to toughen criminal policy?}

In a famous comment, Nils Christie labelled the crime victim as the forgotten party. Indeed, victims were for a long time side-lined in the fields of criminology and criminal policy, focusing on the perpetrators. ${ }^{10}$ The situation has changed radically over the past few decades. The victims' position has become the focus of both national and international policies to an unprecedented level. Lively discussion about the status of the victims has raised awareness as to the features and consequences of victims' experiences and contributed to improving the position of victims. ${ }^{11}$ At the same time, the opinions about the effects of concern with victims on criminal policy are divided.

A striking feature in international discussions has been the creation of a juxtaposition between the perpetrator and the victim. There may be several factors to explain this. The Anglo-American criminal justice system can be characterised as a zero-sum game: it is not possible to support the interests of both parties at the same time; if you give something to one, you are taking something away from the other. There are also tensions between different researchers, research orientations, and criminological schools of thought. Critical criminologists have sought to highlight the ways in which

9 Harrikari, Securitizing Childhood - Childhood and Youth in Finnish Crime Prevention Programmes, 13 Youth justice (2013) pp. 57-72; Koskela, Fear and its others in Handbook of Social Geography, eds. Smith, Pain, Marston and Jones (2009) pp. 389-407; Korander and Törrönen, Zero confidence in youths? Experiences of the zero tolerance experiment in Finland, 13 Young (2005) pp. 47-71; Vesikansa and Honkatukia, School Violence as a Complex Social Problem - Trends in Managing Discipline in Finnish Educational Policy in The Palgrave International Handbook of School Discipline: Surveillance, Punishment and Social Control, eds. Deakin, Taylor and Kupchik (Palgrave Macmillan 2018) pp. 129-148.

10 Christie, Conflicts as Property, 17 The British Journal of Criminology (1977) pp. 1-15.

11 E.g. Walklate, Imagining the Victim of Crime (Open University Press 2007); Hall, Victims and Policy Making: A Comparative Perspective (Willan Publishing 2010); Niemi-Kiesiläinen, Criminal Law or Social Policy as Protection against Violence in Responsible Selves. Women in Nordic Legal Culture, eds. Nousiainen et al (Ashgate 2001) pp. 289-310; Tham, Rönneling, and Rytterbro, The Emergence of the Crime Victim: Sweden in a Scandinavian Context, 40 Crime and Justice in Scandinavia (2011) pp. 555-611. 
using the criminal justice system weakens the position of those targeted by it, i.e., the perpetrators. They have an ambivalent attitude towards feminist-oriented victim studies, where demands have been made for the criminal justice system to more efficiently protect the victim. ${ }^{12}$

Abolitionists Thomas Mathiesen and Ole Kristian Hjemdal take a refreshing view, in which the victim and perpetrator of a crime are no longer treated as each other's opponent. The writers held onto the basic principle of abolitionism. They posit that the use of the criminal justice system against perpetrators should be decreased; and prison sentences, in particular, be abolished. According to them, it would be practical to allocate all freed resources into making sure that judicial officials in the future focus all their attention on the victims of crime and improving their position. ${ }^{13}$

Highlighting the position of victims and improving their position have carried weight in discussions about criminal policy. According to Garland, as the long-neglected victim of crime has become the focus of attention, the voice of victims has become too strong. This, he argues, has contributed to an increase in repression. ${ }^{14}$ This interpretation has led to criticism, especially among those who study victims. ${ }^{15}$ However, Garland may be onto something. In the Anglo-American context, the media and public debate are more strongly linked to decision-making in criminal policy than in Finland. Several analyses of the role of the media have highlighted the way in which sensationalist reporting about individual crimes invites the public to identify with the suffering of the victims. ${ }^{16}$ Empathy toward an individual victim may be short-lived, but, in the long term, the reporting has a negative impact on the public's feeling of security and strengthens the fear of the possibility of becoming the victim of a random street crime. ${ }^{17}$

Garland paints a vivid picture of emotionally appealing rhetoric that draws its strength from the media and popular discussion described above. Victims become the focus of all attention, and their rights must not be trampled on. Protecting them, listening to them, honouring their memories, expressing anger on their behalf, and listening to their fears become crucial. As an example, Garland describes how in the United States,

12 See in detail Rock, Theoretical Perspectives on Victimisation in Handbook of Victims and Victimology, eds. Sandra Walklate (Willian Publishing 2007) pp. 37-61; Walklate 2007.

13 Mathiesen and Hjemdal, A New Look at Victim and Offender - an Abolitionist Approach in What is Criminology?, eds. Bosworth and Hoyle (Oxford University Press 2011) pp. 223-234.

14 Garland 2001.

15 E.g. Rock 2007; Walklate 2007; Aertsen, Punitivity from a victim's perspective in Resisting punitiveness in Europe? Welfare, human rights and democracy, eds. Snacken and Dumortier (Routledge 2012) pp. 202-224.

16 E.g. Elias, Victims Still: The Political Manipulation of Crime Victims (Sage Publications 1993); Demker et al, Fear and Punishment in Sweden: Exploring Penal Attitudes, 10 Punishment \& Society (2008) pp. 319-332.

$17 \quad$ Koskela 2009. 
punishments of several crimes have been increased by laws named after a victim who had suffered from that type of crime, such as Megan's Law or Jenna's Law. ${ }^{18}$

Looking more closely at Garland's analysis, his criticism is not directed at individual victims, but rather at the political and populist discourse, in which a crime victim receives symbolic value. Garland does not in fact claim that the victim movement or persons victimised by crime unanimously call for punishment. He asserts that the British movement associated with supporting victims has tried to avoid taking a position on the severity of punishments, while the U.S. movement for victims' rights has been more closely aligned with 'Law and Order' politics. Even in the United States, however, the claims for harder penalties have played a subsidiary role in relation to other demands by the victim organisations. ${ }^{19}$

Other commentators, too, have emphasised that the victim movement should not be held responsible for toughening criminal policy. Taking a closer look at the role and influence of victim movements in the United Kingdom and the United States, it is misleading to say that calling for punishment is a common characteristic of the various victim movements. ${ }^{20}$ We too question the simplified view of the victim in criminal policy. In the populist rhetoric the victim has been hijacked and turned into a tool for tougher criminal policy without involving genuine interest in what the victims actually desire. Before discussing this question, we will analyse more closely the victim's position in Nordic criminal policy discussion.

18 Garland 2001.

19 Garland 2001. See also Elias 1993; Spalek, Crime Victims: Theory, Policy and Practice (Palgrave Macmillan 2006); Williams and Goodman, The Role of The Voluntary Sector in Handbook of Victims and Victimology, eds. Walklate (Willian Publishing 2007) pp. 240-254; Hall 2010; Mawby, Victim support in England and Wales: the end of an era?, 22 International Review of Victimology (2016) pp. 203-221.

20 E.g. Spalek 2006; Booth and Carrington, Comparative Analysis of the Victim Policies across the Anglo-Speaking World in Handbook of Victims and Victimology, ed. Sandra Walklate (Willan Publishing 2007) pp. 380-415. 


\section{Dangerous crime victims in the Nordic countries}

From a Nordic perspective, the UK and U.S. discussion may feel alien, though there have been signs of a toughening of criminal policy in the Nordic countries as well. ${ }^{21}$ What, then, is the position of the victims in the Nordic discussion? The phenomenon is hard to grasp because Nordic countries differ from one another. The developments described by Garland most closely align with Sweden's. The 1990s brought a shift in the debate on criminal policy, which led to a tightening of control. Criminal policy become the target of general political claims. This has manifested itself in a juxtaposition of crime victims versus suspects. ${ }^{22}$ The position of the victim became particularly central in the media in the $1990 \mathrm{~s}^{23}$

The victim's identity has been a source of debate, and highlighting victim perspectives has, at times, created the impression that such an identity is desirable. ${ }^{24}$ Such views are oversimplifying and may be part of a overheated criminal policy debate. At an individual level, however, few people desire to be a crime victim. Crimes, especially violent crimes, are reported to the police relatively rarely, and usually remain hidden. Being a victim of a crime - especially a violent or sexual crime - is a distressing and traumatic experience. For many people, is not easy to identify themselves as a victim. Many people often internalise an image of the ideal victim: a pure, innocent person who is not connected to the perpetrator or the crime. ${ }^{25}$ This image might not, however, correspond to reality. Typically, there are interactions between victim and perpetrator. This may provoke feelings of guilt and shame in the victims, as well as suspicions in outsiders about the genuineness or decency of the victim. For example, it has been difficult to get victims to participate in an aid system that has been set up for victims of human trafficking. They may know their abusers or/and have reasons to be afraid. They may have come illegally to the country and often they owe money to the traffickers. Consequently, the identities of perpetrator and victim may be intertwined. This,

21 For more detail, see e.g. Pratt, Scandinavian exceptionalism in an era of penal excess: Part I: The nature and roots of Scandinavian exceptionalism, 48 The British Journal of Criminology (2008) pp. 119-137; Pratt, Scandinavian exceptionalism in an era of penal excess: Part II: Does Scandinavian exceptionalism have a future?, 48 The British Journal of Criminology (2007) pp. 275-292; Ugelvik and Dullum (eds.) Penal exceptionalism? Nordic Prison Practice and Policy (Routledge 2011); Todd-Kvam, Bordered penal populism: When populism and Scandinavian exceptionalism meet, 21 Punishment \& Society (2019) pp. 295-314.

22 See e.g. Tham, Rönneling, and Rytterbro 2011; Demker and Duus-Otterström, Realigning criminal policy. Offender and victim in the Swedish party system over time, 19 International Review of Sociology (2009) pp. 273-296.

23 E.g. Pollack, En studie i medier och brott (Stockholms universitet, Institutionen för journalistik, medier och kommunikation 2001); Demker et al 2008.

24 Lernestedt and Tham, (eds.), Brottsoffret och kriminalpolitiken (Norstedts Juridik 2011); Tham, Rönneling, and Rytterbro 2011.

25 Christie, The Ideal Victim in From Crime Policy to Victim Policy, eds. Fattah E.A. (Macmillan 1986) pp. 17-30. 
in turn, blurs and diminishes their status as victims of crime; these individuals may have consented to illegal activity as part of their immigration process and are afraid of being accused of a crime, such as selling sex. They may also not believe that others would believe their story and see them as victims, with good reasons. ${ }^{26}$

In Finland, criminal policy has remained fairly moderate and highlighting the victim's perspective has not provoked strong juxtapositions. For example, the Crime Victims Committee (2001) based its work on the principle that the positions of the victim and suspect are not competitive and that it is possible to respond to both at the same time.$^{27}$ Civil society organisations and other stakeholders that work with crime victims have been moderate and have not profiled themselves as proponents of harsher punishments. The focus has been on developing victim support services and improving the authorities' understanding of victim experiences. There has been little discussion about the severity of punishments, although this question has been raised e.g. in the context of rape cases. ${ }^{28}$

The moderate tone of the discussion may be linked to the fact that the rights of crime victims have historically been strong in the Finnish system. In many other countries, the position of the victim is comparable to that of a witness, but the victim in Finland enjoys several distinct rights as a party to the proceedings. ${ }^{29}$ Somewhat paradoxically, this has prevented criminal policy makers and law drafters from critically assessing the status of crime victims and delayed the launch of a discussion about the vulnerability entailed by victimisation. ${ }^{30}$ Consequently, vulnerability has been poorly recognised and its impact on the criminal justice system has not been discussed. From this per-

26 Roth, Defining human trafficking and identifying its victims: A study on the impact and future challenges of international, European and Finnish legal responses to prostitution-related trafficking in human beings (Martinus Nijhoff Publishers 2011); Ollus and Jokinen, "We've got People Lined Up Behind the Door": Placing the Trafficking and Exploitation of Migrant Workers in Context in the Restaurant and Cleaning Sectors in Finland, Exploitation of Migrant Workers in Finland, Sweden, Estonia and Lithuania: Uncovering the links between recruitment, irregular employment practices and labour trafficking. Institute for Crime Prevention and Control. HEUNI Publication Series 75 (2013) pp. 31-170; Niemi and Aaltonen, Abuse of a victim of sex trade: Evaluation of the Finnish sex purchase ban. Ministry of Justice: Reports and guidelines 13/2014.

27 Ministry of Justice (2001) Rikosuhritoimikunnan mietintö. Helsinki: Oikeusministeriö.

28 Utriainen, Raiskaus rikosoikeudellisena ongelmana (Lapin yliopiston oikeustieteiden tiedekunta 2010).

29 Joutsen, The Role of the Victim of Crime in European Criminal Justice Systems. Helsinki Institute for Crime Prevention and Control. HEUNI. Report Series No. 11. (1987); NiemiKiesiläinen, Rikosprosessi ja parisuhdeväkivalta (WSOY 2004); Kainulainen and Saarikkomäki, Rikosprosessi väkivaltarikosten uhrien näkökulmasta (Oikeuspoliittisen tutkimuslaitoksen tutkimustiedonantoja 2014).

30 Ronkainen, Haavoittunut kansankunta ja väkivallan toimijuus in Väkivalta: Seuraamukset ja haavoittuvuus. Terttu Utriaisen juhlakirja, eds. Lohiniva-Kerkelä (Talentum 2006) pp. 531550; Honkatukia, Uhrit rikosprosessissa: Haavoittuvuus, palvelut ja kohtelu (Oikeuspoliittisen tutkimuslaitoksen tutkimuksia 2011). 
spective, the position of victim has been brought up as a discussion topic in Finland later than in other Western countries. Moreover, there still exists a continued but implicit assumption of strong victims who are able to exercise the rights guaranteed by law, and that this makes their rights readily addressed. ${ }^{31}$ Sensitivity to the vulnerable conditions that may result from the victimisation itself, previous life events or societal status of the victim has emerged only in recent years.

Another contributing factor may be that victim support systems - the Victim Support Finland, Rape Crisis Center Tukinainen and Women's Line - are based on the work of civil society organisations. These organisations have been and still are dependent on project funding by the state, municipalities, and a Finnish Gaming Company Veikkaus. Constant uncertainty about funding and the nature of the services as fill-ins for the welfare state may also have contributed to the reluctance of these organisations to express views contrary to the official line in national criminal policy. ${ }^{32}$

\section{Who is afraid of the crime victim?}

As we have pointed in the article, Finnish criminal policy has focused on keeping the number of inmates low. In Finland, perpetrators of crime have often been considered to be the suffering ones whereas victims as robust individuals. ${ }^{33}$ Elina Pirjatanniemi has highlighted the difficulty as a criminal justice researcher to demand that the system effectively protects the victims. Traditionally, the ultima ratio, 'last resort' principle of criminal justice has been taken seriously and researchers have opposed increased use of criminal justice or repression. ${ }^{34}$

In this narrative, the position of the victim and the perpetrator of crime are at odds. From the victims' point of view, the problem is that their position easily becomes secondary when the expected punishment and the suspect's due process rights define the criminal procedures. The position of the crime victim has been overshadowed by the primary focus of criminal policy. It has been feared that bringing victims' needs and right to the agenda would compromise this focus. Moreover, there has been reluctance among criminal policy planners to deal with criminal policy and criminal justice as gendered phenomena -which may have resulted in little debate on criminal policy

31 Nousiainen, Equalizing Images? Gendered Imagery in Criminal Law, 24 Suomen Antropologi (1999) pp. 7-24; Niemi-Kiesiläinen (2004).

32 Helminen, We need to make sure that we are always something else: Victim support organisations and the increasing responsibility of the state in supporting crime victims in Finland and Norway, 25 International Review of Victimology (2019) pp. 157-179.

33 Nousiainen 1999.

34 Pirjatanniemi, Haastavatko ihmisoikeudet Suomen kriminaalipolitiikan? 2. Oikeus (2011) pp. 154-174; Pirjatanniemi, Vem är rädd för offret?, 5 Tidskrift utgiven av Juridiska Föreningen $i$ Finland (2008) pp. 609-624. 
in Finland. We regard this regrettable as we think that the discussion should include crime victims and focus on the victim's perspective as part of a humane and rational criminal policy. There is no need to silence the discussion out of fear that looking at victims would inevitably lead to more severe penalties.

In populist criminal policy debates, advocates for harsher punishments often speak through the mouth of the victim. In these debates the victim is hijacked as a tool for tougher repression without an attempt on the part of the participants to find out what truly matters to the victim. On an individual level, victims of crime are typically not vengeful. By contrast, a fair and due process will often be more important for many than the sentence. ${ }^{35}$

\section{Victims of crime do not seek punishment}

People's opinions about the appropriate level of punishment can be measured in different ways. It is, hence, essential to know how each study has been conducted. When people are presented with a very generic question about the adequacy of punishment, they tend to view that it is too low. If, however, the respondents are presented with more precise questions, the results often change. Several Nordic studies show that the more informed people are about the crime, its circumstances, and the perpetrator, the more lenient the penalties they are prepared to grant. Interestingly, people usually support sanctions that are more lenient than the existing ones. They may even suggest alternatives to prison. ${ }^{36}$

Opinions about the appropriate level of punishment have also been studied by asking people who themselves have been victims of a crime. The victim's desire for punishment is affected by several factors: the nature of the crime, the relationship between the victim and the perpetrator, the time passed since the crime, support received by the victim, how the case has been dealt with during the criminal process, etc. ${ }^{37}$ Women who have been victims of domestic abuse, for example, usually seek effective action to

$35 \quad$ See e.g. Aertsen 2012.

36 Jerre and Tham, Svenskarnas syn på straff (Stockholms universitet Kriminologiska institutionen 2010); Balvig et al, The public sense of justice in Scandinavia: A study of attitudes towards punishments, 12 European Journal of Criminology (2015) pp. 342-361; Kääriäinen, Seitsemän rikostapausta: käräjätuomareiden arvioima rangaistuskäytäntö ja väestön rangaistusvalinnat. Helsinki: Helsingin yliopisto, Valtiotieteellinen tiedekunta, Kriminologian ja oikeuspolitiikan instituutti. Katsauksia 21/2017. See also Lovegrove, Putting the Offender Back into Sentencing: An Empirical Study of the Public's Understanding of Personal Mitigation, 11 Criminology \& Criminal Justice (2001) pp. 37-57.

$37 \quad$ Kainulainen and Saarikkomäki 2014. 
end the violence - they may believe more in programs aimed at stopping the violence than in punishment. ${ }^{38}$

A victim of a crime may also experience a change of heart during the criminal process. The basic outcome, however, is that victims are not particularly revengeful or eager for punishment in the sense of wanting to cause suffering to the perpetrator. Instead, solutions such as paying compensation or mandating that the perpetrator receive therapy or some other form of treatment may be regarded as punishment. In addition, it is important for many to receive acknowledgement of that they have been wronged and to get the perpetrator to understand the consequences his actions from the victim's perspective. $^{39}$

According to psychological studies the amount of time that has passed since the crime was committed diminishes the demand for punishment. At first, a victim may experience strong feelings of anger and vengefulness, which however often subside as time passes. Most victims gradually adapt to the crime and its consequences. Trauma literature describes how one can learn to accept what has happened and adapt it to be part of one's everyday life. ${ }^{40}$ However, a small number of victims never recover from the traumatising consequences of the crime and, in a sense, remain fixed at the time of the event. These individuals exhibit the greatest feelings of anger and the desire for revenge on the perpetrator. Processing the potential consequences of a victim's experience is crucial not only for the victim's survival, but also because it is likely to reduce the victim's desire for punishment. The victim's adjustment is affected by the way in which the events are addressed during the criminal process. Poor treatment may cause a desire for revenge to linger. ${ }^{41}$

When studying people's experiences with the judicial process, the process is often more important for people than the outcome. ${ }^{42}$ Therefore, the field of international victim studies has focused on how crimes are dealt with during the criminal process. Crime victims have confirmed that the way in which they are treated is important to

38 E.g. Herman, Justice from the Victim's Perspective, 11 Violence Against Women (2005) pp. 571-602; Lewis et al, Protection, prevention, rehabilitation or justice? Women's use of the law to challenge domestic violence, 7 International Review of Victimology (2000) pp. 179-205.

39 See e.g. Shapland, Willmore, and Duff, Victims in the Criminal Justice System (Gower Publishing Company Limited 1985) p. 14; Herman 2005; Bradford, Voice, Neutrality and Respect: Use of Victim Support Services, Procedural Fairness and Confidence in The Criminal Justice System, 11 Criminology \& Criminal Justice (2011) pp. 345-366; Franklyn, Satisfaction and Willingness to Engage with the Criminal Justice System: Findings from the Witness and Victim Experience Survey, 2009-10. Ministry of Justice Research Series 1/1, 2012; Kainulainen and Saarikkomäki 2014.

40 See e.g. Brison, Aftermath: Violence and the Remaking of a Self (Princeton University Press 2002); Orth, Montada, and Maercker, Feelings of Revenge, Retaliation Motive, and Posttraumatic Stress Reactions in Crime Victims, 21 Journal of Interpersonal Violence (2006) pp. 229-243.

$41 \quad$ Brison 2006 pp. 229-243.

42 Tyler, Why People Obey the Law (Yale University Press 1990). 
them. Another vital element is their judicial position as it affects how they are able to act during the judicial process. Many studies support the idea that the victim should have the opportunity of being an active participant in the process of delivering justice. They should be offered the chance to be heard and understood, to contribute to the course of the process, to get information in a comprehensible form during the procedure, and to be a participant during all the stages of the process. ${ }^{43}$

Affirming the victim's right to participate does not mean that decision-making power in all questions should be transferred from the authorities to the victim. Victims do not want that. From their point of view, the decision about whether to file charges can be extremely painful and stressful. Demanding punishment or deciding about the sentence for an intimate partner, a family member, relative or close friend can be demanding and intimidating. It can require an unreasonable resilience from individual victims, and may even endanger their security. Rather, many would prefer that the judicial authorities consult them before making a final decision. This offers the victims an opportunity of being heard, and is therefore an important part of procedural justice. $^{44}$

The judicial position of crime victims in Finland is good, but there is very little information about how victims' rights are exercised in practice. Very few studies have approached this question from the victim's perspective to enquire crime victims' views about the criminal process. ${ }^{45}$ We believe that criminal policy debates should pay attention to the victims and crucially hear what they have to say.

\section{Toward victim sensitivity}

Over the past 20 years, victim sensitivity has significantly increased. It has become a topic in the media, public discussion, and research, and it has inspired pressure for legislative changes. The list of legal changes in Finland is extensive, including among others the introduction of restraining orders in 1999, intra-family restraining order in 2005 , the possibility for the victim to give testimony in court without the presence of the accused in 2003, the restriction of non-prosecution of domestic violence in 2004,

43 Kelly, Victims' Perceptions of Criminal Justice, 11 Pepperdine Law Review (1983) pp. 15-22; Shapland, Willmore and Duff 1985; Lindgren, Brottsoffer i rättsprocessen. Om ideala brottsoffer och goda myndigheter (Jure Förlag AB 2004); Diesen, Terapeutisk Juridik (Liber 2011); Kainulainen and Saarikkomäki 2014.

44 Ford, Prosecution as a Victim Power Resource: A Note on Empowering Women in Violent Conjugal Relationships, 25 Law \& Society Review (1991) pp. 313-334; Hirschel and Hutchison, The Relative Effects of Offence, Offender, and Victim Variables on the Decision to Prosecute Domestic Violence Cases, 7 Violence Against Women (2001) pp. 46-59; Fleury, Missing Voices: Patterns of Battered Women's Satisfaction with the Criminal Legal System, 8 Violence Against Women (2002) pp. 181-205.

45 However, see Honkatukia 2011; Kainulainen and Saarikkomäki 2014. 
the expansion of the definition of rape in 2011 and the expansion of the responsibility for filing child welfare notifications and reporting offenses in 2010-2016.

We may nonetheless ask whether these legislative changes suffice. The reforms have been enacted individually, and there has been no holistic evaluation of legislation from the victim's perspective. The European Council's convention on preventing domestic violence and violence toward women (the Istanbul Convention) was ratified in Finland in 2015. Victims Directive (2012/29/EU) constitutes the core of the European Union legislative package aiming to guarantee victims of crimes access to information, support and protection. Now, the adequacy of the level of protection for victims in Finland, both judicially and in terms of the availability of services should be critically and systematically evaluated.

According to Riikka Kotanen's doctoral thesis, the victim's experience of domestic abuse, initially an invisible crime, is now taken seriously, which has challenged the basic principles of criminal policy. ${ }^{46}$ This change has been partly due to international pressure, and to the calls of media and victim organisations that victim rights are inadequately recognised. The development has not been smooth, as has been described above. At the same time it should be noted that the highlighting of the victim's perspective has not involved the kind of gratuitous, sensationalist reporting on victim experiences as was described by Garland. The most pointed arguments have taken place on social media and in academic discussions when it comes to specific cases. Even here, the subject has usually been discussed on a more general level and moderately.

The position of the victim still needs critical assessment. To conclude, we point to four relatively broad themes where work remains to be done to improve the victim's position. First, we need sensitivity to recognise the diversity and intesectionality of crime victims and their needs. Not all of them are weak, but there are many groups and individuals who, due to their social position, personal history, or other reasons, need special support and help. ${ }^{47}$ Legal actors should strive to recognise the diversity of victims and their varying needs to support them better. This requires abandoning the liberal idea of equality, according to which everyone must be treated the same way. Sensitivity and vigilance are needed to recognise the issues and dynamics that prevent individual victims from getting help, acting rationally, and achieving their rights.

Second, many methods for supporting victims depend on third-sector operators which in turn depend on adequate funding. Third-sector operators have excellent skills and constantly seek to develop customer-oriented operations. Third-sector services also rely on civil society: many offer help by trained activists through volunteer work. Crime victims themselves have given positive feedback about the help they have

46 Kotanen, Näkymättömästä näkökulmaksi. Parisuhdeväkivallan uhrit ja oikeudellisen sääntelyn muutos Suomessa (Sosiaalitieteiden laitoksen julkaisuja 2013).

$47 \quad$ Honkatukia 2011. 
received from such organisations. ${ }^{48}$ The state, i.e. the public authorities, should ensure adequate and permanent funding of these organisations.

Third, we need more research on victims' experiences, needs, and encounters with authorities, simultaneously acknowledging that the victim experience does not automatically translate into unambiguous research data. As indicated earlier, victim experiences may involve strong feelings of shame and guilt. In a postmodern world emphasising individuality, individuals are often made responsible for their own choices and their consequences. Discussion about responsibility is not always divided symmetrically or justly across the intersection of genders, social class, race or other societal divides. ${ }^{49}$ Being a victim may be experienced as a failure and victims may struggle to discuss their experience with others. The victimisation can thus remain a painful experience that is not shared. Relevant information related to that experience may be left out of studies. Better understanding on such sensitive matters requires inspiration from the sociological imagination developed by C. Wright Mills ${ }^{50}$ and a researcher who takes research ethics seriously. This kind of a framework enables the researchers to analyse how the experiences of an individual also speak of one's society. The aim of a researcher should be to thoroughly understand an individual person's suffering and hardships, but also to have the ability to analyse them as general problems and societal issues.

Fourth, we need an understanding of the position of the victim as part of education and training for professionals in many fields, as the Istanbul Convention and Victims Directive underlines. Social services and health care providers encounter many victims of crime who seek to help them deal with the consequences of the event, whether physical, psychological, social, or economic. Police, prosecutors, and judges should also be trained accordingly. The criminal justice system needs more sensitivity to better meet the needs of crime victims and to help them more actively to achieve their rights.

We hope we have been able to convince our readers that there is no need to be afraid of the crime victim. In the beginning of the third decade of the $21^{\text {st }}$ century Finland should be ready for an open and sensible discussion of criminal policy in which the justness and humaneness of the criminal process are evaluated also from the victim's perspective.

48 Honkatukia 2011; Kainulainen, Raped? Sexual Assault in Criminal Proceedings, 51 Scandinavian Studies in Law (2007) pp. 263-279.

49 Ronkainen, Kenen ongelma väkivalta on? Suomalainen hyvinvointivaltio ja väkivallan toimijuus, 73 Yhteiskuntapolitiikka (2008) pp. 388-401.

$50 \quad$ Mills, The sociological imagination (Oxford University Press 2000). 